\title{
トライボロジー教育用実験装置製作を通した 設計教育の試み
}

\author{
An Attempt of Design Education through the Production of Experimental \\ Setups for Tribology Education
}

\section{野口昭 治*1 \\ Shoji NOGUCHI}

\begin{abstract}
This report describes a lesson in design in which students constructed a device as part of their training in tribology. The device consists of a launcher, a basket and a platform. Steel balls are launched and made to bounce three times on the platform before landing in the basket. By conducting preliminary experiments, problems were identified with the prototype and improvements were incorporated in the final design. The students learned new design methods. This exercise provided students with an opportunity to broaden their knowledge of steel materials, geometrical tolerances, guideways for rolling elements, mechanisms, and 3D-CAD. It is anticipated that design education will continue to incorporate the actual construction of such devices as an integral part of design education.
\end{abstract}

Keywords : Mechanical Engineering Education, Students, Practice Education, Design \& Drafting キーワード : 機械工学教育, 学生, 実践教育, 設計製図

\section{1.はじめに}

既報において，実験を併用した大学におけるトライ ボロジー教育について報告した ${ }^{1)}$ ．トライボロジーは 実学が多いため，実験を併用した方が座学だけよりも 理解が哚まると考えて, 講義に出てくる理論をわかり やすく説明・実証するために実験を取り入れた講義を 行ったところ, 座学だけより理解が深まるというアン ケート結果が得られた。既報では実験を併用したこと によるトライボロジー教育効果に主眼をおいたため, 講義で使用した実験装置についての記述は最小限に留 めていた。

講義で用いる実験装置の製作は機械工学科のカリ キュラムではなく, 当研究室学生有志で行っている. 研究としてではなく，将来機械技術者として生きてい くための自主的スキルアップとして取り組んでいる. 年度初めに製作する装置の概要を決め, 必要に応じ て試作実験を行い，12月の講義までに完成させるスケ ジュールを自主的に計画し，毎年 1 台を目標に装置の 製作を行っている．教員は製作する装置のテーマ（概 略）と以下に記す全般的な要求事項を提示するが，そ れ以降は基本的に学生に任せている（質問があれば助 言はするが，解決策は学生に見つけさせる).

（1）出張講義も考慮して，ケースに入れて持ち運び

平成 19 年 12 月 5 日受付

※1東京理科大学理工学部機械工学科
ができること（軽量・可搬）。

（2）装置の複製を考慮して，機械加工を少なくし， 入手性の良い市販部品を多用すること.

（3）小学校低学年でも容易に操作ができること.

（4）実験担当学生は毎年交代するので, 装置の保守 管理が容易であること。

装置の企画立案, 基礎実験, 設計, 図面作成, 組立・ 調整を経て, 所定の結果が得られる装置を完成させる ことは，座学を中心に学んできた学生にとっては容易 ではない，簡単な実験装置であっても実際に作ってみ ることで，座学だけでは得難い様々な設計知識が身に 付いたはずである。本文では, 鋼球を 3 バウンドさせ てターゲットに収める鋼球バスケット装置の製作過程 とそれを通して得られた設計教育の効果について報告 する.

\section{2. 鋼球バスケット装置を用いた講義の目的と実 験装置の概要}

トライボロジー特性が性能に大きく影響する機械要 素は “トライボ機械要素”と呼ばれる ${ }^{21}$. トライボ機 械要素が性能を発揮するためには, 相手と自身の幾何 学的形状精度を高める必要がある。“機械の米” と称 される転がり軸受はその代表であり，転がり軸受を構 成する内外輪, 転動体（玉，ころ）はサブミクロンの 加工精度で作られている。本装置は，簡単な実験で転 がり軸受を構成する部品が高精度であることを実感し 


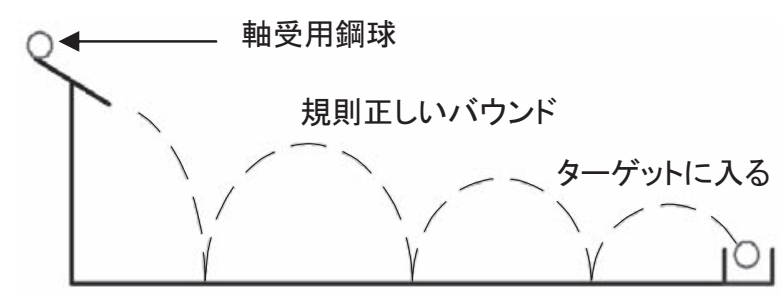

（a）高精度鋼球を使った場合

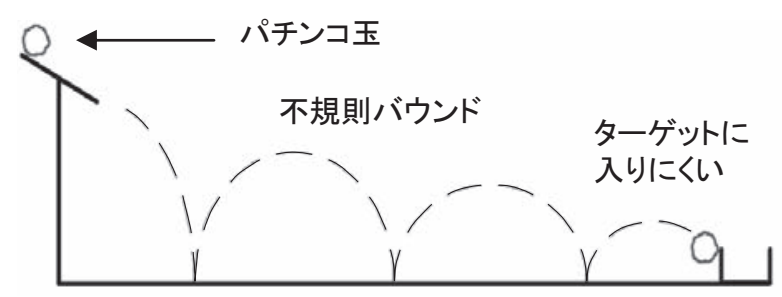

（b）低精度鋼球を使った場合

図 1 鋼球バスケット装置の概念

てもらうことを講義での目的としている.

装置は 2 種類の精度の異なる鋼球（転がり軸受用鋼 球とパチンコ玉）を所定の位置から落下させ， 3 バウ ンドしてターゲットに納める装置である。 バウンドす る様子をドリブル，鋼球がターゲットに収まる様子を バスケットボールのシュートに見立てて，「鋼球バス ケット装置」と命名した。

装置の原理は，鋼球の形状精度がよい場合には規則 正しく（入射角と反射角が同じ）バウンドするので, 最初にターゲットに入るように鋼球落下部を調整すれ ば，以降は繰り返して入る（図 1 (a))。しかし，鋼球 の形状精度が悪い場合には, 跳ね返る方向が前後左右 に乱れるので，バウンドを繰り返すと累積誤差が大き くなり，狙ったターゲットに入り難くなると考えられ る（図 $1(\mathrm{~b}))$. 高等学校までに学んだ知識から容易 に原理を理解することができる装置である。

\section{3. 実験装置の試作と改良}

\section{1 動作確認のための実験}

予備実験も兼ねて最初に組んだ装置の写真を図 2 に 示す. 硬い表面でバウンドさせる必要があると考えて,

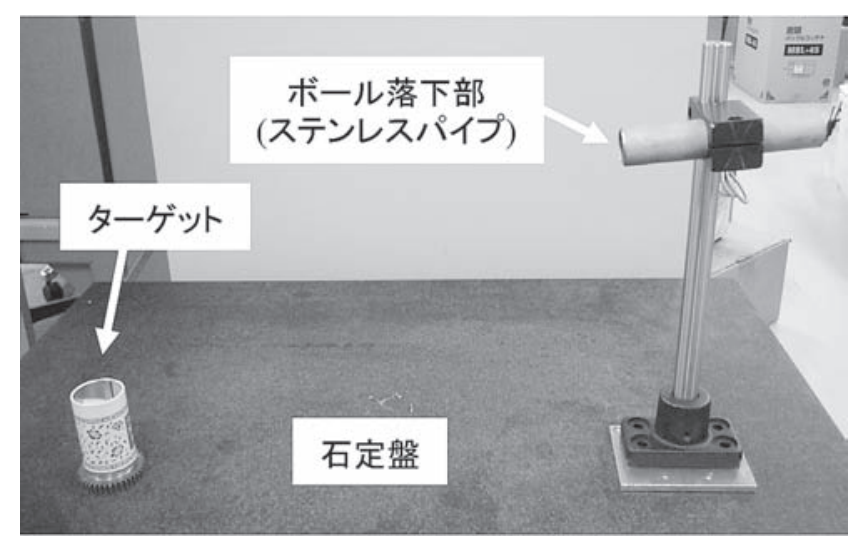

図 2 試作実験装置
石定盤上に装置を組んで行った，鋼球を落下させる部 分には, 鋼球より少し大きな内径穴のステンレスパイ プに切り达みを入れて, 薄板片を挿入・除去すること によって鋼球を一定の位置から落下させた. ターゲッ トには内径 $25 \mathrm{~mm}$ の小缶を使用した。

軸受用鋼球とパチンコ玉の反発係数については，同 じ高さから石定盤に落下させる実験 $(300 \mathrm{~mm}$ の高さ から落下させて, 跳ね返る様子をVTRで撮影して跳 ね返った高さを測定）を行って，軸受用鋼球0.866, パチンコ玉0.864が得られた。ほとんど同じであり， 軸受用鋼球とパチンコ玉でターゲットの位置を変える 必要はないことがわかった。 また，2つの鋼球の直径 は $11 \mathrm{~mm}$, 形状誤差 (真円度) は図 3 に示すように軸 受用鋼球 $0.4 \mu \mathrm{m}$ （精度等級 G 40），パチンコ玉 $17.1 \mu \mathrm{m} て ゙$ あり，パチンコ玉の方が 2 桁大きな值であった。

鋼球を落下させる部分の傾斜, 高さを決めて, 転が り軸受用鋼球を落下させ， 3 バウンドして入るように 小缶の位置を調整した後, 予備実験を行った。結果は 第 2 章の予想通りで, 軸受用鋼球を使うとかなりの確 率でターゲットに入り，パチンコ玉を使うと軸受用鋼 球よりもターゲットに入る確率が低くなることが確認 できた。しかし，繰り返して実験を行っていると 300 回を超えたあたりから，軸受用鋼球でもターゲットか ら外れる回数が徐々に多くなってきた。 その原因は, 石定盤に圧痕が出来たことであった（図 4 , 手触りで 確認)。鋼球が硬すぎて, 何度も同じ箇所に落下を繰 り返すうちに圧痕ができてしまい, バウンドして跳ね

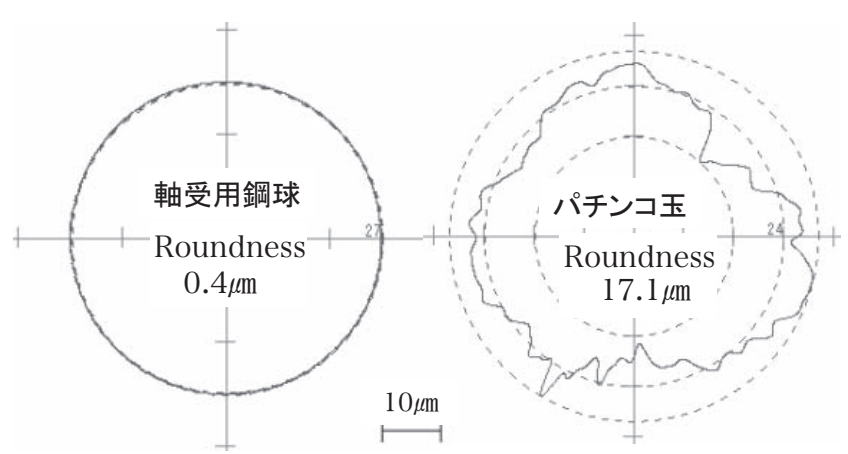

図 3 軸受用鋼球とパチンコ玉の真円度

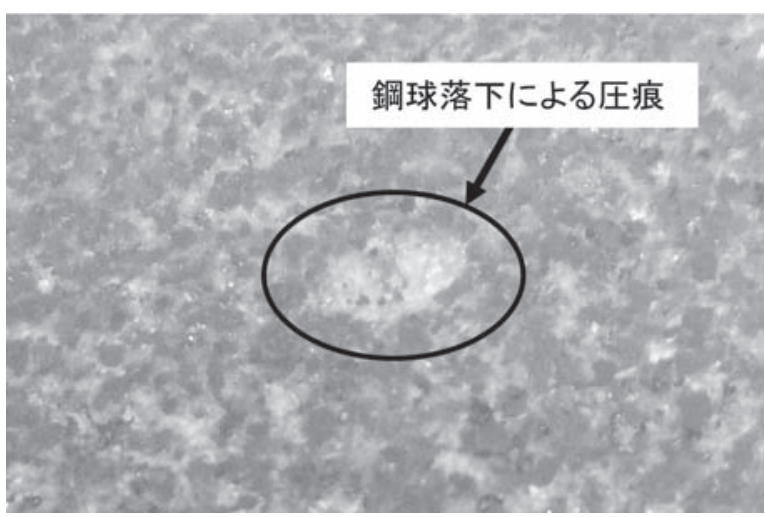

図 4 石定盤にできた圧痕 
返る方向が初期とは違ってきたためと考えられる.

また，この実験では鋼球を落下させる際の案内にパ イプを使っていたが，鋼球を止めている薄板除去時に 振動があった場合には，鋼球は左右に摇れながら管内 を転がり落ちることも確認された，パイプから落下す る際の方向がずれることもターゲットに入らない原因 と考えられる. 動作確認のための実験としては狙った 結果が得られたが, 実験の再現性を向上させるには, 改良する点があることも明らかになった。

\section{2 装置の改良と製作}

前節の予備実験での結果を基に講義で実際に使用す る装置の設計・製作を行った。予備実験装置からの改 良点を以下に記す。

(1) バウンド箇所の改良

鋼球が連続して落下しても圧痕が付かないように, バウンドする部分を鋼球より硬くする必要があること がわかった．セラミック定盤の使用も検討したが，高 価であること，重くて携帯できないこと等があり断念 した．鋼球がバウンドする箇所を含めた小さな領域だ け硬いことが必要と考えて, 焼入れしてHv1000以上 にした粉末高速度工具鋼（HAP10）の板を研磨して,

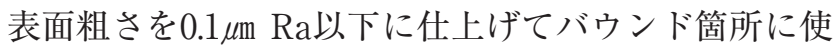
用した。

バウンド板（縦 $50 \mathrm{~mm}$, 横 $50 \mathrm{~mm}$, 高さ $10 \mathrm{~mm}$ ）を 図 5 に示す。初期バウンド位置の調整や長期使用に よって疲労した場合にはバウンド位置を容易に変えら れるようにするため, 装置へ固定する穴は長穴とした. もちろん, 表裏両面とも研磨してあり, 両面がバウン ド表面として使えるようにしてある。

(2) 鋼球案内部の改良

鋼球の落下を安定させるためには，案内部において 安定して鋼球が転がる必要がある，また，実演中に埃 等異物が付着することも考えられるが，その際には簡 単に除去できる必要がある。 そこで安定した転がりが 得られる 2 面拘束，案内面が開放されていることの必 要性からV溝案内とした。

（3）鋼球落下の安定化と実験の自動化

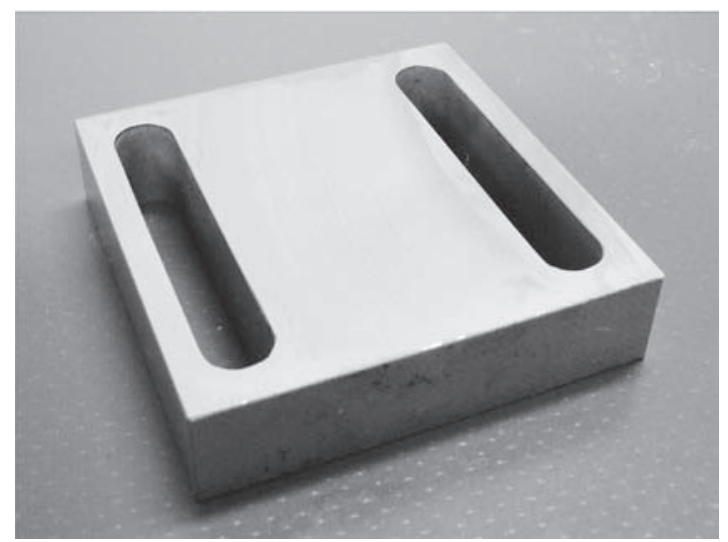

図 5 鋼球バウンド板
手動での鋼球投入は誤差があること, 長期の繰り返 し実験ができないことから，鋼球を循環させるための リフタを追加して, 鋼球落下からバウンドしてバス ケットに入るまでを自動化し, 複数の鋼球を用いた自 動実験をできるようにした（リフタは市販玩具 ${ }^{3)}$ か ら転用)。その際，鋼球が連なって落下しないように 仕切りを 2 重にして, 上部で一旦停止させ, 1 個ずつ 下部へ送られて落下させるようにした。図 6 に鋼球落 下部の 3 D-CADモデルと実物の写真を示す． 2 枚の 仕切り板は, モー夕駆動で交互に動くようなリンク機 構で構成されている（どこでも使用できるように電源 は乾電池).

また， 3 バウンドしてターゲットに入った鋼球は循 環させて, 連続的な実験が行えるようにしたが, ター ゲットからの鋼球排出を簡略化するためにターゲット は樹脂積層型ラピッドプロトタイピング装置を用い て製作した (ABS樹脂). 循環部へ導く部分が斜め下 へ伸びているが, 本体部分と一体で成形されている (図 7 ). 鋼球の質量は $10 \mathrm{~g}$ もないので, 部品を組み 立てて製作しなくても強度的に十分であるとともに,

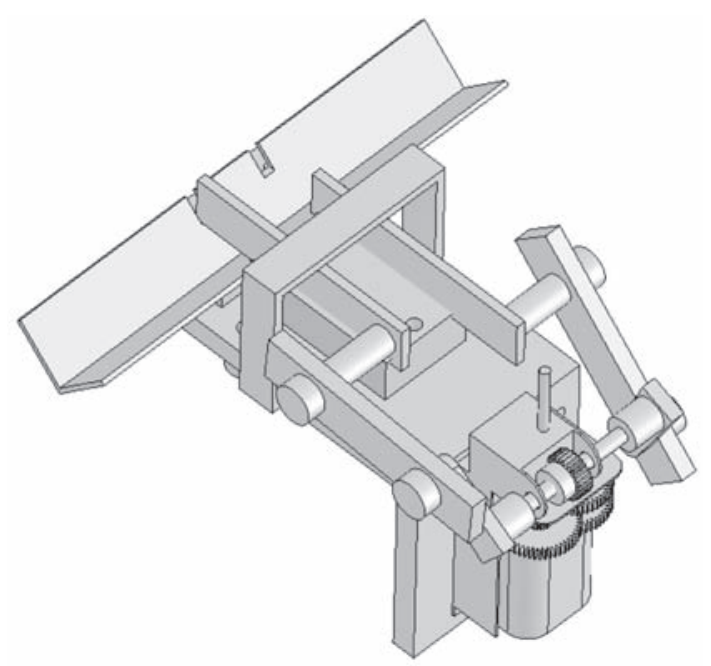

(a) 鋼球落下機構 3 D-CAD 図

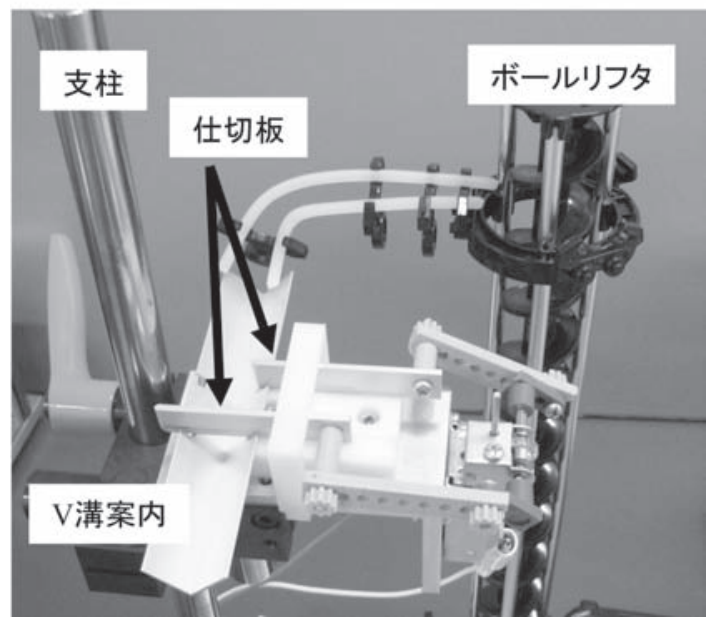

(b) 鋼球落下機構写真

図 6 鋼球落下機構 


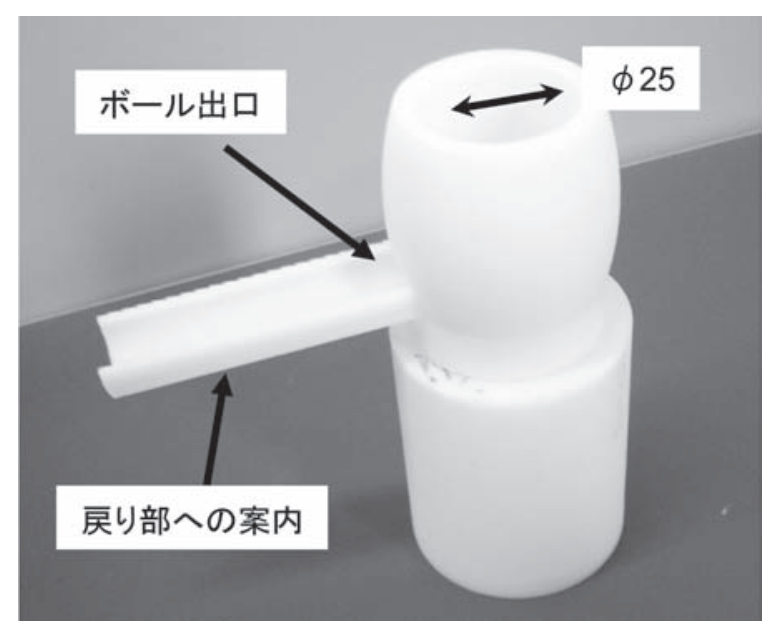

図 7 ラピッドプロトタイピング装置で製作したター ゲット部

3 D-CAD/CAMの実習も兼ねている.

これらの改良を加えて製作した装置の写真を図 8 に 示す。この装置を用いて, 鋼球を循環させて実験を行 い,ターゲットに入る割合を求めた，パチンコ玉は約 $20 \%$ 割合でしか入らないが, 軸受用鋼球は90\%以上 の割合で入ることがわかった（後述表 1 )。講義にお

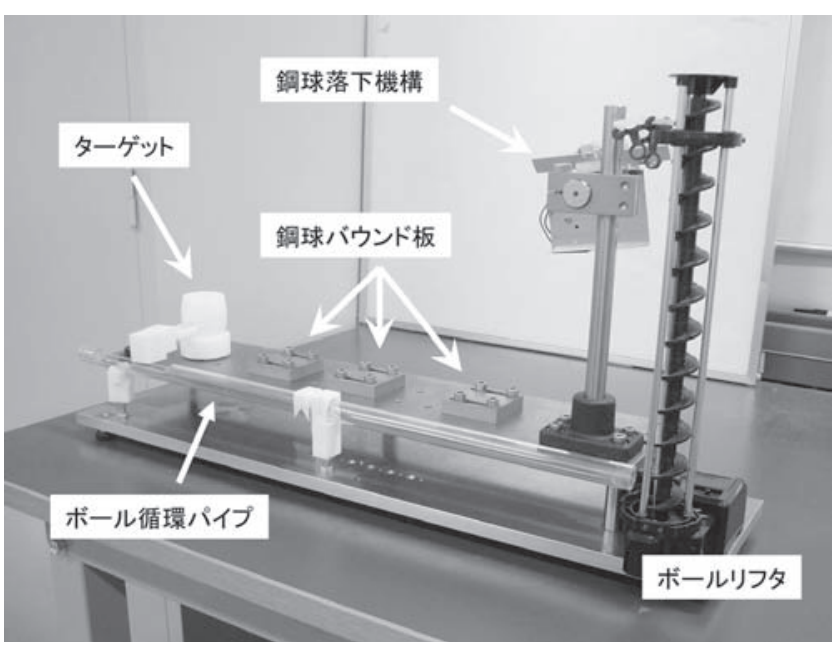

図 8 鋼球バスケット装置
表 1 ターゲットに入る確率一覧

\begin{tabular}{|l|c|c|}
\hline & 1 号機 & 2 号機 \\
\hline パチンコ玉 & 0.22 & 0.08 \\
\hline 軸受用鋼球 & 0.92 & 0.84 \\
\hline マスターボール & 0.99 & 0.96 \\
\hline
\end{tabular}

いては，それぞれ 5 個の鋼球を循環させて，すべての 鋼球がターゲットから外れるまでを実演した。 パチン コ玉は10回程度の循環ですべて外れてしまったが，軸 受用鋼球ではなかなか外れないため, 時間の都合で実 験を途中で止めなければならなかった。一般的には形 状誤差 (真円度) $20 \mu \mathrm{m}$ は高精度と考えられるが，この ような単純な実験であっても再現性は得られない。軸 受用鋼球がいかに高精度であるかを実感させることが できたと考える.

\section{3 新型装置の製作}

前節までに鋼球を 3 バウンドさせてターゲットへ入 れるバスケット装置の設計・製作における工夫を述べ た。講義で実演した後のアンケートではかなり好評で あったが1), 装置の改良についての設問では動きが単 純であるという回答が複数あった。そこで鋼球の動き を複雑にしてターゲットに入れる装置の設計・製作を 行った. 3.2 節の装置を 1 号機（以降 1 号機），本節

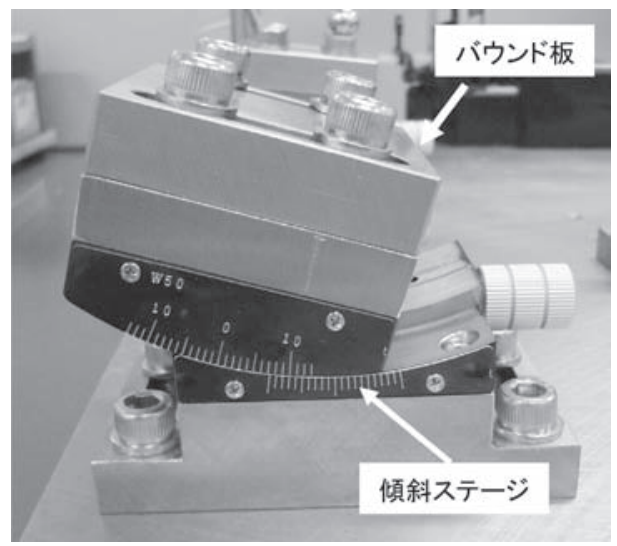

図 9 傾斜させた鋼球バウンド部
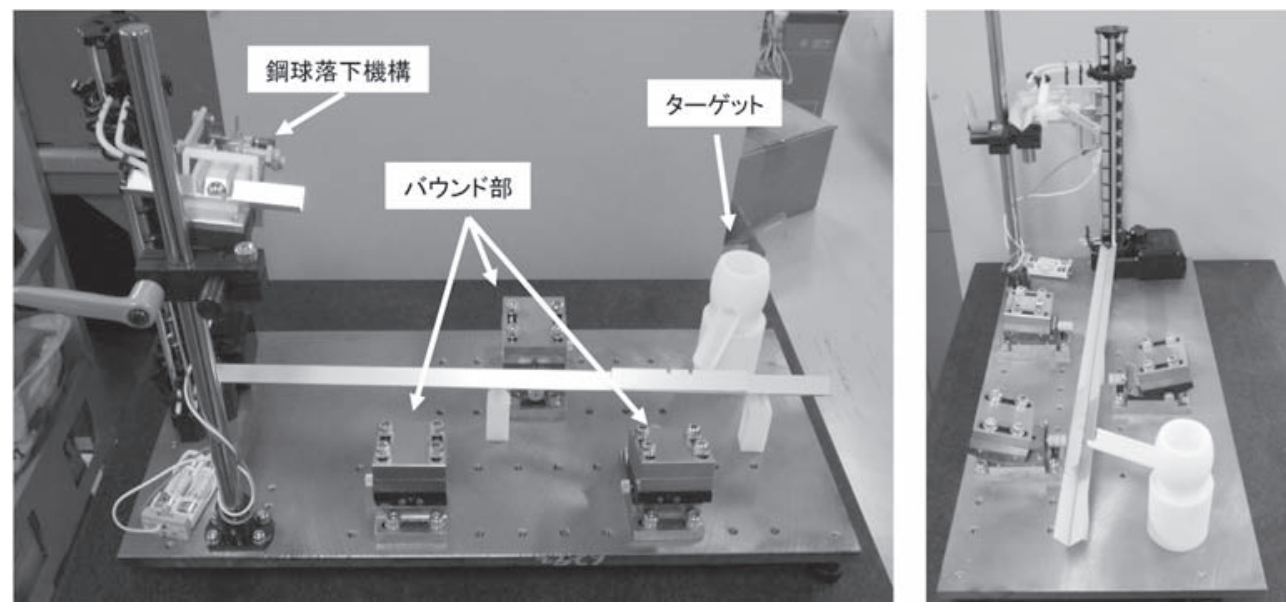

図 10 鋼球バスケット装置 2 号機 
の装置を 2 号機（以降 2 号機）と呼ぶことにする.

1 号機は落下・バウンドする方向が一直線であった. 鋼球投入案内部での転がり（自転）方向とも一致して おり, ターゲットに最も入りやすい構造であったと考 えられる。そこで 2 号機は，バウンド板を内側に傾斜 させて，バウンドの方向を千鳥状にしてターゲットに 入れる装置を考えた。

図 9 にバウンド板部分の詳細を示す.バウンド板自 体は図 5 に示したものと同じであるが，傾斜ステージ 上にバウンド板を固定した． 1 号機と同じように 3 バ ウンドさせるので, 微小な調整ができる方が有利と考 えて, 装置としては高価になるが, 傾斜角度は固定で はなく傾斜ステージを使って角度調節を可能にした. 2 号機の写真を図10に示す.

ターゲットに入る確率をまとめて表 1 に示すが，同 じ鋼球を用いた場合でも 2 号機は 1 号機よりも入る確 率が悪くなっていることがわかる. 2 号機は鋼球落下 時の自転方向とバウンドする方向が異なるので, 鋼球 の形状誤差の影響が顕著に現れたためと考えられる. そこで，軸受用鋼球の精度を向上させたマスタボー ルを用いて追加実験を行った。 マスタボール（直径 $11.113 \mathrm{~mm} ）$ の形状を図11に示す。真円度は $0.07 \mu \mathrm{m} て ゙$ あり，図 3 に示した軸受用鋼球よりも高精度である. 高精度のマスタボールを使用すると 2 号機における確 率は向上しており, 鋼球の形状精度とターゲットに入 る確率は関係深いことがわかる.

\section{4. 装置製作を通した設計教育効果}

トライボロジー教育教材である 3 バウンドさせて ターゲットに鋼球を入れるバスケット装置について説 明した，原理は単純であるが，装置が完成するまでに は動作確認の予備実験に始まり，不具合の抽出とその 対策が必要であった。装置製作に参加した学生にアン ケートを行って，この装置製作を通して得られた新た な知識, 深められた知識等について調査した。結果を 以下に示すが (順不同)，これらが本装置の製作を通し た設計教育の効果であると考えられる.

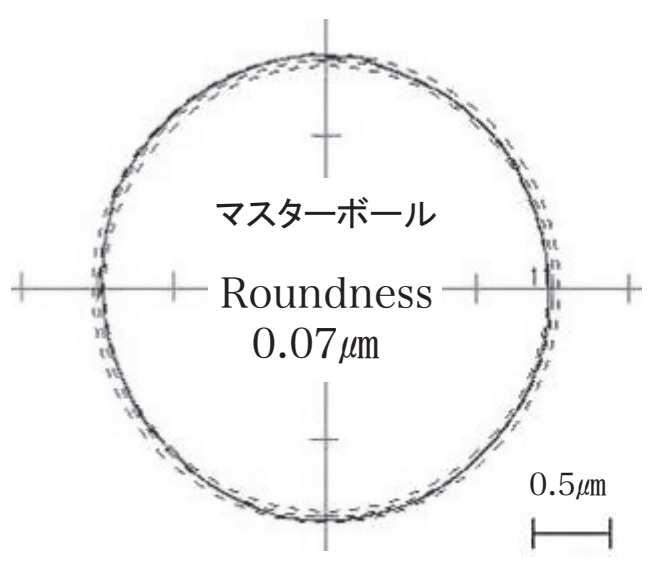

図 11 マスターボールの真円度
（1）真円度・真球度等の幾何公差の知識

パチンコ玉と軸受用鋼球の形状計測を通した真円 度, 真球度定義の再認識とミクロンレベルの形状誤差 に起因する反発不具合現象の認識.

(2) 硬さの知識

硬いと思われた石定盤の表面であっても鋼球が同じ 場所に落下し続けると圧痕ができてしまう現象を通し ての硬さに対する意識の再確認と衝撃耐久性に関する 経験.

（3）表面形状（粗さ）の知識

衝突する表面の形状が悪いと安定した反発が得られ ないことへの認識.

（4）焼入れを含めた鉄鋼材料の知識

バウンド板に使用した特殊な工具鋼や硬さを出すた めに必要な焼入れの知識.

(5) 転がり案内の知識

安定した鋼球の転がりを得るための運動拘束や案内 方法の知識.

(6) 移動ステージの知識

ゴニオステージの構造や簡単なステージが市販され ていることへの知識.

(7) 機構学の知識

鋼球落下部分での 2 枚仕切り板を交互に動かすため の機構設計と製作.

(8) 3 D-CADの知識と技能習得

設計に用いた 3 D-CAD（SolidWorks）の知識とモ デル作成能力の向上.

(9) ラピッドプロトタイピングの知識

3D-CADから直接モデルを製作するラピッドプロト タイピングに関する知識と実際の製作を通して得られ た製品感覚.

（10）市販品の価格並びに購入方法

装置に使用する機械要素, 鋼板, 支柱等はできる限 り市販されているものを購入させた. 市販の部品・製 品価格に関する感覚.

（11）コストに対する認識向上

市販品の購入，機械加工の費用等を含めて，製作す る装置のコストを考えて設計するような意識.

\section{5.おわりに}

本報ではトライボロジーの講義で使用する「鋼球バ スケット装置」の製作を通した設計教育について報告 した．簡単な装置であっても機能の実現までには多く の問題点・改良点があった，学生にとっては装置の概 念設計, 予備実験, 3 D-CADを使ったモデル・眓面 作成, コストを意識した部品選定・購入, ラピッドプ ロトタイピング装置を使った部品製作, 組立・調整, 実験の実演まで経験することができて, 有効な設計教 育になったと考えられる。特にコストに関しては，大 学の講義だけでは実感がないままで終わってしまった 
と考えられる。

今後も 1 年に 1 台の割合でこのような教育用実験装 置を製作し，その製作を通して実践的な設計教育を 行っていきたいと考えている.

\section{文献}

1）野口昭治：実験を導入したトライボロジー教育の 試み, 工学教育, 55-5,pp15-19, 2007

2) 日本トライボロジー学会：トライボロジー入門(ト ライボロジーにおける基本技術), 2006

3 ）株式会社バンダイ：SPACE WARP. http://www. bandai.co.jp/releases/J2005011401.html

\section{著者紹介}

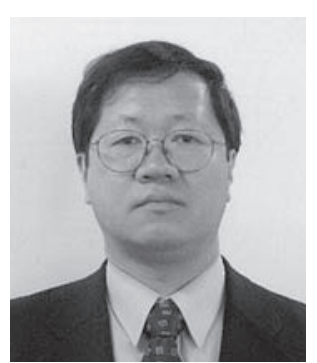

\section{野口＼cjkstart昭治}

1985年東京工業大学大学院理工学研究科 生産機械工学専攻修士課程修了, 博士（工 学)。日本精工株式会社を経て, 2002年 4 月より東京理科大学理工学部機械工学科.

専門：転がり軸受工学, トライボロ ジー, 精密計測

所属学会: 日本機械学会, 日本トライボ ロジー学会, 精密工学会, 日 本設計工学会, 日本工学教育 協会

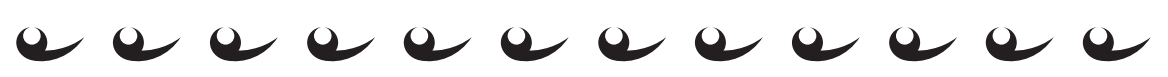

